Павелко О. В. [1; ORCID ID: 0000-0002-2483-2245], д.е.Н., професор,

Велігурська А. М. [1; ORCID ID: 0000-0002-4261-9739], здобувач другого (магістерського) рівня вищої освіти, Лівенда К. 0. [1; ORCID ID: 0000-0001-9442-7619], здобувач другого (магістерського) рівня вищої освіти

${ }^{1}$ Національний університет водного господарства та природокористування, м. Рівне

\title{
ОРГАНІЗАЦІЯ ОБЛІКУ ПАЛИВА ЯК СКЛАДОВА ІНФОРМАЦІЙНОГО ЗАБЕЗПЕЧЕННЯ УПРАВЛІННЯ ЕКОЛОГІЧНИМ СЛІДОМ
}

У статті досліджено ідентифікацію організації бухгалтерського обліку, запропоновано їі авторське тлумачення. Визначено етапи організації облікового процесу палива як одного 3 головних вичерпних та дороговартісних ресурсів для роботи автомобілів, що під час згоряння у двигуні спричиняє викиди небезпечних для здоров'я людей та довкілля речовин. Встановлено, що узагальнення інформації про обсяги використаного палива $\epsilon$ необхідною умовою оцінки рівня викидів забруднюючих речовин в атмосферу, вжиття дієвих заходів для зниження рівня антропогенного впливу на навколишнє середовище, що своєю чергою відображається в показнику «екологічний слід». Наведено форми статистичної звітності, які містять відомості про паливо та обсяги його використання. Охарактеризовано відповідні показники статистичної звітності. Проаналізовано вміст основних забруднюючих речовин в атмосферному повітрі міст Україні за даними спостережень гідрометеорологічних організацій. Досліджено динаміку викидів забруднюючих речовин в атмосферне повітря України за 2000-2010 pp.

Ключові слова: організація обліку; паливо; інформаційне забезпечення; управління; екологічний слід.

Актуальність теми. Актуальність обраної теми зумовлена тим, що внаслідок забруднення повітря від згорання палива значно погіршується екологічний слід та якість навколишнього природного середовища. Відтак, в умовах сьогодення необхідно слідкувати за наявністю та дотриманням законодавчо визначеної бази з питань порушень норм шкідливих викидів. Надзвичайно важливо підтримувати нормальний рівень якості повітря, адже нехтування цим питанням $€$ причиною значної кількості захворювань та смертей, зокрема через такі хвороби, як ішемічна хвороба серця, 
пневмонія, інсульт, хронічне обструктивне захворювання легень, рак легень та ін.

Окрім того, багато підприємств використовують неекологічні способи виробництва, на які припадає основна частина викидів в навколишнє природне середовище. При цьому їхня діяльність не контролюється державою, а залишається «на совісті» підприємств. Також суттєво впливає на якість навколишнього природного середовища кількість автотранспортних засобів, які перманентно здійснюють викиди, забруднюючи довкілля. Відтак, нині вкрай важливо досліджувати дану тематику, контролювати діяльність підприємств за допомогою законодавчого регулювання 3 метою підтримання належного рівня якості повітря та водночас популяризувати альтернативні джерела енергії.

Важливу роль при цьому відіграє організація обліку, адже вдале їі налагодження сприятиме формуванню достовірної інформації, що пред'являється користувачам звітності, в томі числі і статистичної, яка впливає на формування зведених показників на рівні країни і оприлюднюється на сайті Державної служби статистики України.

Аналіз останніх досліджень і публікацій. Дослідження основних засад організації бухгалтерського обліку, побудови облікового процесу, його етапів спостерігається в публікаціях багатьох вітчизняних науковців, зокрема таких, як: Жук В. М., Кужельний М. В., Левицька С. О., Лень В. С., Пархоменко В. М., Сопко В. В., СукП. Л. та ін. Однак, незважаючи на значний внесок перелічених учених у розвиток базових аспектів організації обліку, значна частка праць за окресленою тематикою має всеохоплюючий характер. Відтак, висвітлення етапів організації обліку саме палива з подальшим відображенням у звітності і розгляд наслідків його споживання в частині впливу на екологічний слід вважаємо актуальним.

Постановка завдання. Мета дослідження полягає в ідентифікації сутності організації обліку, окресленні етапів облікового процесу палива, висвітленні механізму відображення інформації про паливо в статистичній звітності, визначенні динаміки викидів забруднюючих речовин в атмосферне повітря.

Викладення основного матеріалу. 3 метою належного функціонування обліку як інформаційного забезпечення бізнесу значної уваги потребують питання його організації, що передбачає впорядкування та вдосконалення механізму, структури і процесів обліку в межах конкретного господарюючого суб'єкта. В 
економічній літературі нині існують різноманітні підходи до визначення поняття «організація бухгалтерського обліку» (табл. 1).

Таблиця 1

Тлумачення поняття «організація бухгалтерського обліку»

\begin{tabular}{|c|c|c|}
\hline № & Автор & Визначення \\
\hline 1. & $\begin{array}{l}\text { Безруких } \\
\text { П. С. }\end{array}$ & $\begin{array}{l}\text { Науково-обгрунтована сукупність умов, за якої } \\
\text { найбільш економно і раціонально здійснюється збір, } \\
\text { обробка і збереження облікової інформації в умовах } \\
\begin{array}{l}\text { оперативного контролю } \\
\text { використанням засобів }\end{array} \text { за правильним }\end{array}$ \\
\hline 2. & $\begin{array}{l}\text { Бутинець } \\
\text { Ф. Ф. }\end{array}$ & $\begin{array}{l}\text { Система умов та елементів побудови облікового } \\
\text { процесу } 3 \text { метою отримання достовірної та } \\
\text { своєчасної інформації про господарську діяльність } \\
\text { підприємства, здійснення контролю за раціональним } \\
\text { використанням виробничих ресурсів і готової } \\
\text { продукції }\end{array}$ \\
\hline 3. & $\begin{array}{l}\text { Войналович } \\
\text { о.П. }\end{array}$ & $\begin{array}{l}\text { Сукупність заходів із упорядкування облікової } \\
\text { роботи, які здійснює адміністрація підприємства та } \\
\text { бухгалтер за дорученням власника } 3 \text { метою } \\
\text { забезпечення виконання завдань бухгалтерського } \\
\text { обліку на відповідному етапі розвитку суспільства }\end{array}$ \\
\hline 4. & $\begin{array}{l}\text { Карпушенко } \\
\text { М. Ю. }\end{array}$ & $\begin{array}{l}\text { Система впорядкованих дій зі створення системи } \\
\text { бухгалтерського обліку, що включає складання } \\
\text { облікових регістрів і первинних носіїв облікової } \\
\text { інформації, облікову політику підприємства, } \\
\text { організацію облікового процесу }\end{array}$ \\
\hline 5. & $\begin{array}{l}\text { Кашаєв } \\
\text { А. Н. }\end{array}$ & $\begin{array}{l}\text { Сукупність елементів облікового процесу в їх } \\
\text { статичному і динамічному стані, які забезпечують } \\
\text { найбільш активну дію на процеси виконання плану, } \\
\text { а також збереження виробничих ресурсів } \\
\text { дотримання режиму економії }\end{array}$ \\
\hline 6. & $\begin{array}{l}\text { Кужельний } \\
\text { М.В., } \\
\text { Левицька } \\
\text { С. } 0 .\end{array}$ & $\begin{array}{l}\text { Пошук раціональної системи відображення операцій } \\
\text { і результатів діяльності з урахуванням економіко- } \\
\text { організаційних особливостей підприємства, } \\
\text { результати впровадження якої гарантують } \\
\text { достовірність інформації, їі повноцінність для } \\
\text { прийняття оперативнихта стратегічних рішень }\end{array}$ \\
\hline 7. & Лень В. С. & $\begin{array}{l}\text { Сукупність дій зі створення цілісної системи } \\
\text { бухгалтерського обліку, підтримання і підвищення } \\
\text { рівня ї̈ організованості, функціонування якої } \\
\text { спрямоване на забезпечення інформаційних потреб } \\
\text { користувачів, включаючи вибір форм організації та } \\
\text { формування матеріального й інформаційного } \\
\text { забезпечення облікового процесу }\end{array}$ \\
\hline
\end{tabular}


продовження табл. 1

\begin{tabular}{|c|c|c|}
\hline 8. & $\begin{array}{l}\text { Лузан Ю.Я., } \\
\text { Михайлов } \\
\text { М. Г., } \\
\text { Жук В. М. }\end{array}$ & $\begin{array}{l}\text { Комплекс заходів керівника (власника) } \\
\text { підприємства, спрямованих на забезпечення збору, } \\
\text { реєстрації та узагальнення фактів господарської } \\
\text { діяльності з метою отримання достовірної інформації } \\
\text { для прийняття управлінських рішень }\end{array}$ \\
\hline 9. & $\begin{array}{l}\text { Пархоменко } \\
\text { В.М., } \\
\text { Жук В. М. }\end{array}$ & $\begin{array}{l}\text { Система дій, необхідних для побудови облікового } \\
\text { процесу } 3 \text { метою отримання інформації про } \\
\text { господарські процеси, їх групування залежно від } \\
\text { економічного значення та реєстрація у відповідних } \\
\text { реґістрах, здійснення контролю за раціональним } \\
\text { використанням виробничих ресурсів }\end{array}$ \\
\hline 10. & Сопко В. В. & 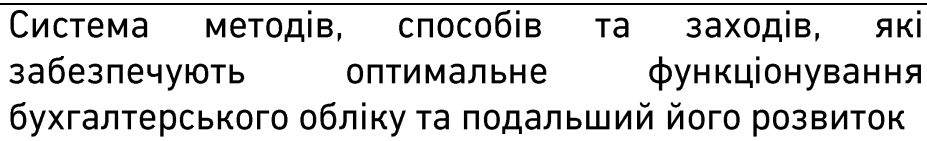 \\
\hline 11. & Сук П. Л. & $\begin{array}{l}\text { Комплекс заходів, спрямованих на } \\
\text { раціональної системи бухгалтерського обліку та ведення } \\
\text { його відповідно до діючих вимогі і завдань }\end{array}$ \\
\hline 12. & Шмігель О. Д. & $\begin{array}{l}\text { Цілеспрямоване впорядкування і удосконалення } \\
\text { методології і техніки бухгалтерського обліку, а також } \\
\text { робочих процесів збору первинної обліково-економічної } \\
\text { інформації, її обробка, узагальнення і отримання } \\
\text { відомостей, необхіднихдля управління підприємством }\end{array}$ \\
\hline
\end{tabular}

Джерело: систематизовано авторами на основі [1-5].

Дані табл. 1 свідчать про те, що науковці розглядають організацію бухгалтерського обліку переважно як сукупність умов, необхідних для належного здійснення бухгалтерського обліку; комплекс дій, заходів зі створення раціональної системи бухгалтерського обліку, забезпечення оптимальності їі функціонування; впорядкування та об'єднання методів, техніки, процесів бухгалтерського обліку для ефективного виконання покладеного на нього завдань та функцій. При цьому вчені звертають особливу увагу на мету раціональної організації облікового процесу - надання оперативної, повної, доречної та достовірної інформації про фінансовий стан, результати діяльності підприємства для прийняття зважених управлінських рішень; здійснення належного контролю за оптимальним використанням активів суб'єкта господарювання. Відтак, на основі аналізу наведених вище підходів до трактування даного поняття, вважаємо, що організація бухгалтерського обліку - комплекс заходів, дій та методів, спрямованих на побудову, впорядкування й удосконалення системи бухгалтерського обліку 3 метою здійснення його контрольної функції за раціональним використанням ресурсів та 
створення підґрунтя задля формування достовірної інформації, необхідної для потреб управління.

Бухгалтерський облік має низку підсистем нижчого рівня: облік необоротних активів, оборотних активів, розрахунків, заробітної плати тощо. Така ідентифікація дає змогу оптимально встановити завдання кожної із підсистем, визначаючи відповідні організаційні та інформаційні моделі. Своєю чергою, кожна ділянка бухгалтерського обліку охоплює ряд елементів. Так, до прикладу, облік оборотних активів передбачає облік виробничих запасів, зокрема, палива, викиди від використання якого в атмосферу надходять досить значні. Це чинить негативний вплив на екологію, адже паливо $€$ одним із головних дороговартісних ресурсів для роботи автомобілів, який під час згоряння у двигуні автомобіля спричиняє викиди небезпечних для здоров'я людей та довкілля речовин. На законодавчому рівні термін «паливо» визначено як речовину, що застосовується для отримання теплової енергії [6]. Водночас, паливом для двигунів внутрішнього згоряння $\epsilon$ нафтопродукти, скраплений газ, паливо моторне альтернативне, паливо моторне сумішеве, речовини, що використовуються як компоненти моторних палив [7].

Паливо для цілей бухгалтерського обліку, відносять переважно до виробничих запасів (за винятком суб'єктів господарювання, що здійснюють його придбання для подальшого перепродажу) - предметів праці, необхідних для забезпечення безперервного процесу виробництва, що повністю переносять свою вартість на виготовлену продукцію, виконані роботи та надані послуги. Серед основних завдань бухгалтерського обліку палива належне документування операцій, пов'язаних 3 його рухом (оприбуткування, внутрішнє переміщення, списання); контроль за його надходженням, зберіганням на складі, раціональним використанням; виявлення наднормативних витрат, що $\epsilon$ відправною точкою для вжиття заходів, спрямованих на оптимізацію операційних витрат, припинення використання палива не за господарським призначенням та зниження негативного впливу на навколишнє природне середовище загалом.

Процес організації бухгалтерського обліку традиційно поділяють на такі три етапи:

1. Методичний (вибір способів та прийомів, що $є$ основою для застосування елементів методу бухгалтерського обліку: документування, інвентаризації, подвійного запису, використання синтетичних та аналітичних рахунків, оцінки майна та зобов'язань, калькулювання, балансу, звітності); 
2. Технічний (вибір форми бухгалтерського обліку, що найбільш повно враховуватиме специфіку діяльності підприємства; способу обробки інформації (ручний, автоматизований); розробка переліку облікових регістрів; встановлення порядку здійснення у них записів та перенесення відповідних даних до форм звітності);

3. Організаційний (налагодження роботи облікового апарату: визначення оптимальної структури бухгалтерії, чисельності бухгалтерів; організація робочих місць; встановлення норм праці та часу для виконання завдань; забезпечення належного рівня діловодства та документообігу; організація матеріального, інформаційного та технічного забезпечення бухгалтерів тощо) [1; 2].

Слід відмітити, що одним із важливих питань організації бухгалтерського обліку та планування діяльності суб'єкта господарювання в цілому $\epsilon$ формування облікової політики, що забезпечує впорядкування та оптимізацію системи бухгалтерського обліку, надання їй цілісності та планомірності, дотримання єдиної методики збору, обробки та узагальнення інформації. Наказ (положення чи розпорядження) про облікову політику відображає принципи, методи та процедури для ведення бухгалтерського обліку, вибір яких здійснюється на основі професійного судження облікового працівника [2]. Для забезпечення належного ведення бухгалтерського обліку палива необхідним $€$ зазначення у наказі про облікову політику одиниці бухгалтерського обліку палива (найменування, однорідна група тощо); методу оцінки вибуття палива (ідентифікованої собівартості відповідної одиниці палива, середньозваженої собівартості, собівартості першого за часом надходження палива; нормативних затрат, ціни продажу); періодичності визначення середньозваженої собівартості одиниці палива (у разі вибору відповідного методу оцінки вибуття) [8], проведення інвентаризації; використання аналітичних рахунків (для обліку палива у розрізі видів, конкретних марок, способів розрахунку за придбання, місць зберігання, матеріальновідповідальних осіб тощо); первинного документу, на підставі якого здійснюється списання палива та ін.

Особливої уваги заслуговують і способи розрахунку за придбане паливо: готівковий та безготівковий. Своєю чергою безготівковий спосіб розрахунку може супроводжуватися складанням:

- відомостей (ґрунтуються на укладанні договору та формуванні інформації про обсяг палива, реалізованого на автозаправній станції (далі - АЗС). Оплата за відомостями здійснюється зазвичай на умовах післяплати); 
- талонами (придбаваються за умовами та відпускною ціною встановленого номіналу, що підтверджує право їх власника на отримання фіксованої кількості нафтопродукту певного найменування і марки на АЗС);

- смарт-картками (спеціальний платіжний засіб у вигляді емітованої в установленому чинним законодавством порядку пластикової чи іншого виду картки для переказу коштів з рахунку платника на рахунок отримувача для оплати вартості палива);

- скретч-картками (одноразові платіжні картки, на рахунку яких наявна відповідна кількість конкретного виду палива; від талонів відрізняються лише формою) [9].

Варто зауважити, що передумовою здійснення безготівкового розрахунку за придбане паливо $\epsilon$ встановлення договірних відносин з постачальником шляхом укладання з ним у письмовій формі договору, в якому зазначається вид та марка палива, його вартість, перелік автозаправних станцій, які його реалізують, спосіб отримання, момент переходу права власності та ін. Для планування потреби суб'єкта господарювання у відповідній кількості конкретного виду палива, здійснення належного контролю за його раціональним використанням, важливим $\epsilon$ нормування витрат палива на автомобільному транспорті. При цьому слід керуватись рекомендаціями, наведеними у Нормах витрат палива і мастильних матеріалів на автомобільному транспорті, затвердженими наказом Міністерства транспорту України від 10.02.1998 № 43. Розрахунок нормативних витрат палива здійснюється із застосуванням відповідних норм (базова лінійна норма на пробіг автомобіля, виконання транспортної роботи, поїздку 3 вантажем, роботу спеціального обладнання, роботу автономного обігрівача) та коефіцієнтів коригування, які враховують дорожні, кліматичні та інші фактори експлуатації [10].

Господарюючі суб'єкти систематично, забезпечуючи дії щодо виявлення, вимірювання, реєстрації, накопичення, узагальнення, зберігання та передачі інформації про діяльність зовнішнім та внутрішнім користувачам для прийняття рішень, здійснюють реалізацію облікового процесу. У його складі виділяють три технологічні стадії (етапи): первинний облік (процес накопичення інформації, що складається 3 первинного спостереження, тобто сприйняття господарських операцій, їх вимірювання у натуральних та вартісних показниках, фіксації у документах; поточний облік (підготовка первинної інформації до обробки, контроль її достовірності, обробка, запис показників документів в облікових регістрах); підсумковий етап (формування звітних показників за 
певний період та надання користувачам підсумкової інформації).

Етапи облікового процесу палива наведено на рис. 1.

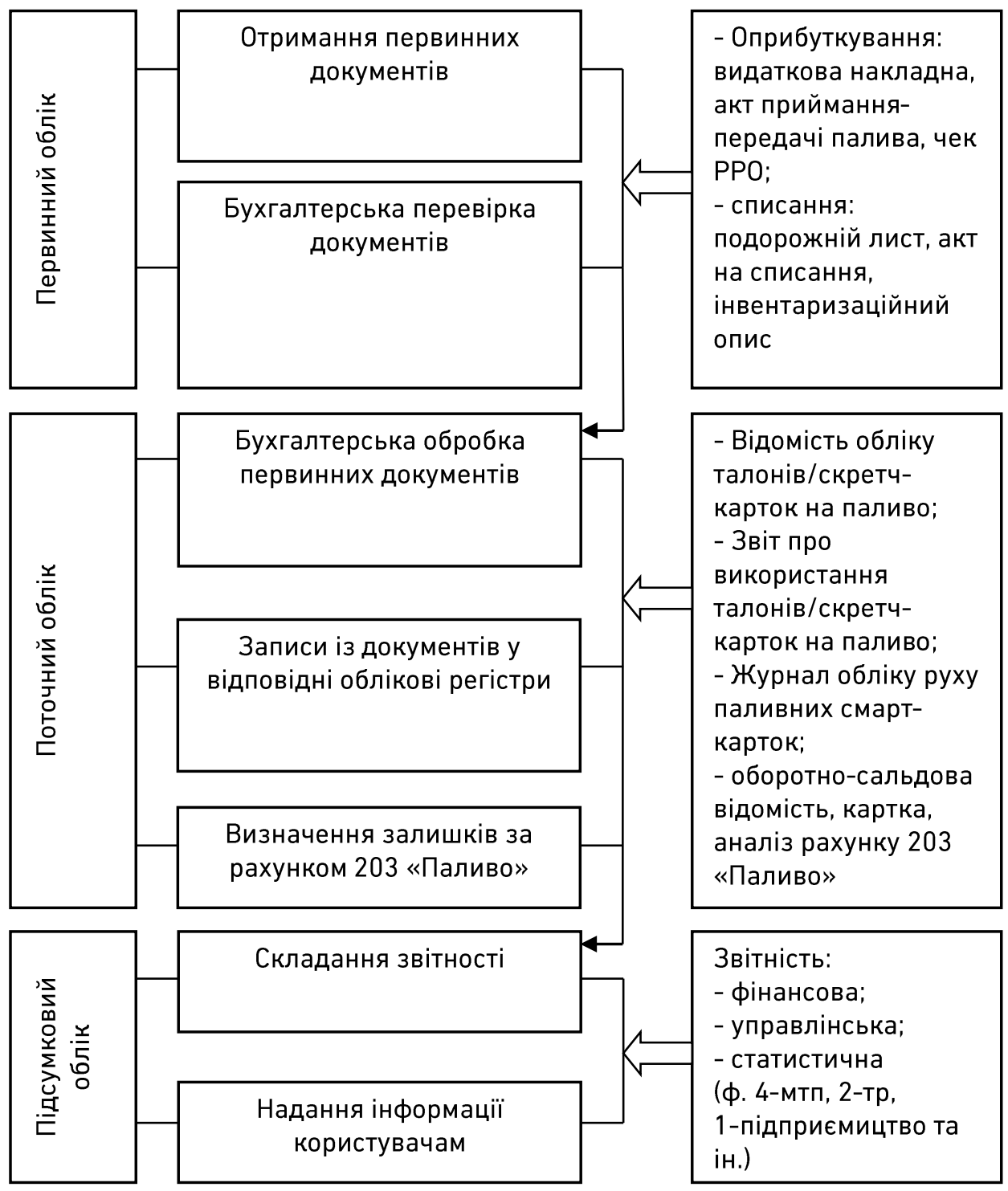

Рис. 1. Етапи облікового процесу палива

Інформація про паливо відображається у балансі (звіті про фінансовий стан). Його споживання впливає на величину матеріальних витрат, що фіксується у звіті про фінансові результати (звіті про сукупний дохід). Більш детальна інформація наводиться у Примітках до річної фінансової звітності. Однак, серед видів звітності, що містить дані про обсяги виробленого, реалізованого та витраченого палива, найбільш інформативною $\epsilon$ статистична (табл. 2), що дає змогу проаналізувати використання палива. 
Форми статистичної звітності, які містять відомості про паливо та обсяги його використання

\begin{tabular}{|c|c|c|c|}
\hline $\begin{array}{l}\text { № } \\
\text { // } \\
\text { / }\end{array}$ & Назва форми & Респонденти & Показники \\
\hline 1 & 2 & 3 & 4 \\
\hline 1. & $\begin{array}{c}\text { Звіт про } \\
\text { використання } \\
\text { та запаси } \\
\text { палива } \\
\text { (ф. № 4-мтп } \\
\text { (річна)) }\end{array}$ & $\begin{array}{c}\text { Юридичні } \\
\text { особи, } \\
\text { відокремлені } \\
\text { підрозділи } \\
\text { юридичних } \\
\text { осіб, які } \\
\text { використову- } \\
\text { ють та/або } \\
\text { мають у } \\
\text { запасах паливо }\end{array}$ & $\begin{array}{l}\text { - У розділі } 1 \text { наведено обсяг } \\
\text { використаного палива за звітний рік та } \\
\text { залишків палива у споживачів та } \\
\text { постачальників на кінець звітного } \\
\text { періоду (за видами палива); } \\
\text { - у розділі } 2 \text { відображено обсяги } \\
\text { палива, використаних на } \\
\text { перетворення енергетичним } \\
\text { сектором; } \\
\text { - у розділі } 3 \text { міститься інформація про } \\
\text { обсяги палива: використаного для } \\
\text { неенергетичних цілей, перевезення } \\
\text { наземним, морським та повітряним } \\
\text { транспортом, підприємствами; } \\
\text { реалізованого населенню (включаючи } \\
\text { працівників підприємства); } \\
\text {-у розділі } 4 \text { висвітлено обсяги втрат } \\
\text { палива при транспортуванні, } \\
\text { розподілі, зберіганні та з інших } \\
\text { причин (безповоротні втрати, } \\
\text { крадіжки тощо) }\end{array}$ \\
\hline 2. & $\begin{array}{l}\text { Звіт про } \\
\text { використання } \\
\text { та запаси } \\
\text { палива } \\
\text { (ф. № 4-мтп } \\
\text { (місячна)) }\end{array}$ & & $\begin{array}{l}\text { Звіт містить лише } 1 \text { таблицю, в якій } \\
\text { наведено обсяги використаного } \\
\text { палива за звітний місяць та запасів } \\
\text { палива на кінець звітного місяця }\end{array}$ \\
\hline 3. & $\begin{array}{c}\text { Звіт про роботу } \\
\text { автотранспорт } \\
\text { y } \\
\text { (ф. № 2-тр } \\
\text { (річна)) }\end{array}$ & $\begin{array}{l}\text { Юридичні } \\
\text { особи, } \\
\text { відокремлені } \\
\text { підрозділи } \\
\text { юридичних } \\
\text { осіб }\end{array}$ & \begin{tabular}{|l} 
3віт містить лише 1 таблицю, в якій \\
наведено загальний пробіг вантажних, \\
легкових, спеціальних автомобілів та \\
автобусів, в тому числі пробіг, який \\
виконано на бензині, дизельному \\
пальному, зрідженому нафтовому газі, \\
стисненому природному газі тощо
\end{tabular} \\
\hline 4. & $\begin{array}{c}\text { Структурне } \\
\text { обстеження } \\
\text { підприємства } \\
\text { (ф. № 1- } \\
\text { підприємництво } \\
\text { (річна)) }\end{array}$ & $\begin{array}{c}\text { Юридичні } \\
\text { особи }\end{array}$ & $\begin{array}{l}\text { - У розділі } 3 \text { графі } 7 \text { наведено } \\
\text { загальні матеріальні витрати та } \\
\text { витрати на оплату послуг, } \\
\text { використані у виробництві продукції } \\
\text { (товарів, послуг) за видами } \\
\text { економічної діяльності (у тис. грн); } \\
\text { - у розділі } 4 \text { відображено детальний }\end{array}$ \\
\hline
\end{tabular}




\begin{tabular}{|c|c|c|c|}
\hline & & & розподіл матеріальних витрат та \\
\hline & & & продовження табл. 2 \\
\hline 1 & 2 & 3 & 4 \\
\hline & & & $\begin{array}{l}\text { витрат на оплату послуг, зазначених } \\
\text { вище, за видами продукції (послуг). } \\
\text { Інформація про витрачені продукти } \\
\text { нафтоперероблення (бензин, } \\
\text { гас,газойлі (дизельне паливо), оливи } \\
\text { та мастила нафтові, торф'яні брикети } \\
\text { тощо) (у тис. грн) міститься у рядку } \\
\text { 419; } \\
\text { - у розділі } 5 \text { висвітлено витрати на } \\
\text { придбання енергопродуктів для } \\
\text { власних потреб (крім використаних як } \\
\text { сировина та для перепродажу) (у тис. } \\
\text { грн); } \\
\text {-у розділі } 7 \text { наведено залишки } \\
\text { виробничих запасів (сировина, } \\
\text { основні й допоміжні матеріали, } \\
\text { комплектуючі вироби та інші } \\
\text { матеріальні цінності, в тому числі } \\
\text { малоцінні та швидкозношувані } \\
\text { предмети) на початок та кінець } \\
\text { звітного періоду (у тис. грн) }\end{array}$ \\
\hline
\end{tabular}

Зведені показники на рівні ДССУ уможливлюють виявлення його втрат в цілому по країні та окремо по регіонах. Збирання, реєстрація та узагальнення інформації про обсяги використаного палива та його запасів за відповідний звітний період на рівні окремого підприємства та систематизація цих показників, їх комплексний аналіз на рівні держави $\epsilon$ необхідною умовою оцінки рівня викидів забруднюючих речовин в атмосферу, виявлення неекономного використання палива, його втрат та, як результат, вжиття оперативних та дієвих заходів для зниження рівня антропогенного впливу на навколишнє середовище, що своєю чергою відображається в показнику «екологічний слід». Вперше, поняття «екологічний слід» було озвучено на Конвенції ООН 1992-го року у Ріо-де-Жанейро під час доповіді «Екологічні сліди країн світу». Подане поняття означає кількісне вимірювання витрат ресурсів екосистем планети для забезпечення попиту людей. Він дозволяє у глобальному вимірі обрахувати вплив людини на довкілля. Розраховується як для окремої людини, так і для групи людей, і представляється площею біологічно продуктивної поверхні суходолу та води, необхідної як для постачання природних ресурсів, що споживаються людиною чи групою людей, так і для поглинання 
відходів, пов'язаних з цим споживанням [11].

Питання впливу людської діяльності на навколишнє середовище і формування екологічного впливу відображено у дослідженні «Environmental Research Letters», що проводилося у 2017 р. Вченими проаналізовано 39 рецензованих статей, урядових звітів і веб-програм, які оцінюють, як вибір способу життя людини може зменшити свою особисту частку викидів. За результатами цього дослідження було встановлено, що для мінімізації свого екологічного сліду кожній людині важливо здійснити такі зміни у способі свого життя: «пересісти» 3 власного на громадський вид транспорту; замінити звичайні лампи на світлодіоди; перманентно сортувати сміття; прати одяг у холодній воді. Проте, було визначено, що перераховані аспекти не дадуть очікуваного позитивного ефекту для зменшення екологічного сліду. Вченими виявлено, що існує лише чотири основні аспекти способу життя людей, які мають значний позитивний вплив на формування екологічного сліду як окремих індивідів, так і держав: перехід до вегетеріанства чи веганства, відмова від авіатранспорту, зменшення використання власного автотранспорту та розумний підхід до планування й народження дітей [12].

Підтвердженням важливості результатів дослідження «Environmental Research Letters» стало повідомлення World Scientists' Warning to Humanity 2017-го року, підписане більш, ніж 15000 вченими 3 усього світу, що містило підтвердження важливості закликання людей «...переглядати і змінювати нашу індивідуальну поведінку, включаючи обмеження нашого власного відтворення і різко зменшити споживання викопного палива, м'яса та інших ресурсів на душу населення» [13]. Окрім цього, через рік (у 2018 р.) видання «Science» опублікувало подібні результати дослідження щодо згубного впливу тваринної промисловості на навколишнє природне середовище. Керівник дослідницької групи Джозеф Пур з Оксфордського університету (Великобританія) зазначив: «Веганська дієта, ймовірно, $€$ найбільшим способом зменшити вплив на планету «Земля» не тільки парникових газів, але і глобального закислення, евтрофікації, землекористування та використання води» [14]. Підтвердженням актуальності проблем забруднення довкілля транспортною інфраструктурою слугують дані аналітичного центру автопрому України, згідно з якими Україна займає 5-те місце серед країн Європи за рівнем смертності від забруднення повітря [15]. Згідно з даними Державної екологічної інспекції України «...у викидах автомобілів знаходяться такі шкідливі речовини, як угарний газ, окиси азоту, тверді частинки та 
летючі органічні з'єднання. Кожен автомобіль при згорянні 1 кг бензину використовує 15 кг повітря, зокрема 5,5 кг кисню. При згорянні 1 т палива в атмосферу викидається 200 кг окису вуглецю» [16]. Гази, викинуті транспортом у навколишнє середовище, сприяють утворенню парникового ефекту, що провокує глобальне потепління. Перевикористання ресурсів, зокрема і палива, $є$ одним із чинників впливу на формування екологічного сліду. Гази, які виділяються внаслідок спалювання палива у двигунах внутрішнього згоряння, мають більше 200 найменувань шкідливих речовин. У своєму складі вихлопні гази містять чадний та вуглекислий газ, оксиди азоту, вуглеводні, сажу, бензпірен та важкі метали. В табл. 3 відображено кількісний аналіз забруднюючих речовин та парникових газів, які виділяються в навколишне природне середовище від споживання палива (бензину, дизельного палива) під час роботи всіх видів транспорту, промислової, сільськогосподарської, будівельної та іншої техніки.

Таблиця 3

Вміст основних забруднюючих речовин в атмосферному повітрі міст Україні заданими спостережень гідрометеорологічних організацій у

першому півріччі 2021 p.

\begin{tabular}{|c|c|c|c|c|c|c|}
\hline Речовина & 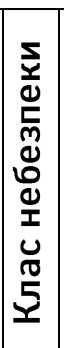 & 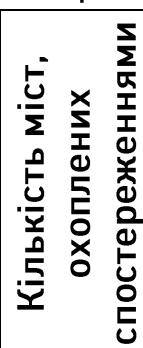 & 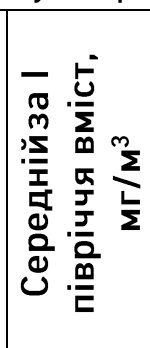 & 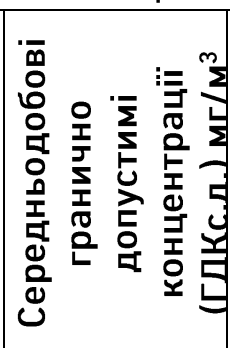 & $\begin{array}{l}\text { Макси- } \\
\text { маль- } \\
\text { ний } \\
\text { вміст, } \\
\mathrm{Mr} / \mathrm{M}^{3}\end{array}$ & $\begin{array}{c}\text { Максимальнд } \\
\text { разові } \\
\text { гранично } \\
\text { допустимі } \\
\text { концент. } \\
\text { (ГДКм.р.) } \\
\text { мг/м³ }\end{array}$ \\
\hline Завислі речовини & 3 & 38 & 0,12 & 0,15 & 2,1 & 0,5 \\
\hline Діоксид сірки & 3 & 38 & 0,018 & 0,050 & 0,289 & 0,500 \\
\hline Оксид вуглецю & 4 & 37 & 1,4 & 3,0 & 23,0 & 5,0 \\
\hline Діоксид азоту & 3 & 38 & 0,06 & 0,04 & 0,80 & 0,20 \\
\hline Оксид азоту & 3 & 22 & 0,04 & 0,06 & 0,44 & 0,40 \\
\hline Сірководень & 2 & 10 & 0,002 & $-^{*}$ & 0,016 & 0,008 \\
\hline Фенол & 2 & 17 & 0,003 & 0,003 & 0,037 & 0,010 \\
\hline Фтористий водень & 2 & 17 & 0,003 & 0,005 & 0,055 & 0,020 \\
\hline Хлористий водень & 2 & 11 & 0,05 & 0,20 & 0,76 & 0,20 \\
\hline міак & 4 & 10 & 0,01 & 0,04 & 0,23 & 0,20 \\
\hline оормальдегі, & 2 & 16 & 0,006 & 0,003 & 0,098 & 0,035 \\
\hline
\end{tabular}
Джерело: [17]

Представлені в табл. 3 значення показників формуються Центральною геофізичною обсерваторією Імені Бориса 
Срезневського за даними мережі спостережень національної гідрометслужби України, які отримані у 38 містах на 128 стаціонарних постах. Отже, можна стверджувати, що у першому півріччі 2021 р. було перевищення допустимих концентрацій речовин відносно середньодобових щодо таких показників: формальдегіду - в 2,0 рази; діоксиду азоту - в 1,5 рази. Вміст фенолу досягнув рівня 1,0 ГДК с.д.

Відповідно до комплексного індексу забруднення атмосферного повітря міст України у першому півріччі 2021 р. до топ-5 найбільш забруднених міст належать: Кам'янське (13,7 ум.од. - за комплексним індексом забруднення атмосфери (КІЗА); Маріуполь (13,7 ум. од.); Одеса (11,8 ум. од.); Дніпро (11,0 ум. од.); Кривий Ріг (10,8 ум. од.). На 38-му місці знаходиться м. Горішні Плавні з показником 2,0 ум. од. Для того, щоб дізнатися, як змінювався якісний та кількісний склад повітря відносно шкідливих речовин, пропонуємо дослідити динаміку таких викидів впродовж 2000-2020 рр. (табл. 4,5).

Таблиця 4 Динаміка викидів забруднюючих речовин в атмосферне повітря України за 2000-2010 рр.

\begin{tabular}{|c|c|c|c|c|c|c|c|c|}
\hline $\begin{array}{c}\text { Назва } \\
\text { речовин } \\
\text { и }\end{array}$ & $\mid \begin{array}{c}\text { Діоксид } \\
\text { сірки } \\
\left(\mathrm{SO}_{2}\right)\end{array}$ & $\begin{array}{c}\text { Оксиди } \\
\text { азоту } \\
\left(\mathrm{NO}_{2}\right)\end{array}$ & $\begin{array}{c}\text { Неметанові } \\
\text { леткі } \\
\text { органічні } \\
\text { сполуки } \\
\text { (НМЛОС) }\end{array}$ & $\begin{array}{l}\text { Аміак } \\
\left(\mathrm{NH}_{3}\right)\end{array}$ & $\begin{array}{c}\text { Оксид } \\
\text { вуглецю } \\
\text { (СО) }\end{array}$ & \begin{tabular}{|} 
Загальний \\
обсяг 34 \\
(З3Ч)
\end{tabular} & $\mathrm{TU}_{10} / \mathrm{PM} 10$ & $\begin{array}{c}\mathrm{TU}_{25} \\
/ \mathrm{PM} 2.5\end{array}$ \\
\hline Рік & \multicolumn{8}{|c|}{1000 т / рік } \\
\hline 2000 & 984,8 & 440,6 & * & 8,3 & 2776,8 & 729,6 & * & * \\
\hline 2001 & 992,1 & 452,0 & * & 8,4 & 2852,5 & 763,9 & $*$ & * \\
\hline 2002 & 1032,6 & 435,7 & * & 8,1 & 2865,1 & 708,8 & * & * \\
\hline 2003 & 1046,3 & 477,9 & * & 8,4 & 2889,6 & 693,2 & * & * \\
\hline 2004 & 988,5 & 471,9 & 97,0 & 14,6 & 2991,0 & 639,5 & 154,7 & 74,7 \\
\hline 2005 & 1132,8 & 523,9 & 96,5 & 17,9 & 2975,2 & 741,7 & 175,7 & 70,2 \\
\hline 2006 & 1347,2 & 515,1 & 94,7 & 19,4 & 3050,5 & 719,9 & 159,3 & 50,4 \\
\hline 2007 & 1342,6 & 641,9 & 372,3 & 20,3 & 3301,5 & 729,9 & 153,3 & 49,3 \\
\hline 2008 & 1320,6 & 642,0 & 382,0 & 19,8 & 3176,7 & 668,2 & 151,3 & 46,4 \\
\hline 2009 & 1262,7 & 562,1 & 358,5 & 21,9 & 2787,5 & 554,0 & 122,9 & 37,7 \\
\hline 2010 & 1235,2 & 603,7 & 359,3 & 25,1 & 2951,9 & 594,5 & 133,2 & 40,7 \\
\hline
\end{tabular}

Динаміка викидів шкідливих речовин у повітря впродовж 2000-2010 рр. дає можливість зробити висновок про те, що найменш забрудненим було повітря у 2004 р. $-2189,2$ т/рік. 
Таблиця 5

Динаміка викидів забруднюючих речовин в атмосферне повітря

України за 2011-2020 рр.

\begin{tabular}{|c|c|c|c|c|c|c|c|c|}
\hline $\begin{array}{c}\text { Назва } \\
\text { речовин } \\
\text { и }\end{array}$ & $\mid \begin{array}{c}\text { Діоксид } \\
\text { сірки } \\
\left(\mathrm{SO}_{2}\right)\end{array}$ & $\begin{array}{c}\text { Оксиди } \\
\text { азоту } \\
\left(\mathrm{NO}_{2}\right)\end{array}$ & $\begin{array}{c}\text { Неметанові } \\
\text { леткі } \\
\text { органічні } \\
\text { сполуки } \\
\text { (НМЛОС) }\end{array}$ & $\begin{array}{l}\text { Аміак } \\
\left(\mathrm{NH}_{3}\right)\end{array}$ & $\begin{array}{c}\text { Оксид } \\
\text { вуглецю } \\
\text { (СО) }\end{array}$ & $\mid \begin{array}{c}\text { Загальний } \\
\text { обсяг 34 } \\
\text { (З3Ч) }\end{array}$ & $\mathrm{TY}_{10} / \mathrm{PM} 10$ & $\begin{array}{c}\mathrm{TU}_{25} \\
/ \mathrm{PM} 2.5\end{array}$ \\
\hline Рік & \multicolumn{8}{|c|}{1000 т / рік } \\
\hline 2011 & 1363,4 & 633,0 & 350,8 & 25,9 & 2908,2 & 641,0 & 142,3 & 42,3 \\
\hline 2012 & 1430,3 & 634,6 & 338,1 & 24,0 & 2830,5 & 609,6 & 135,1 & 34,5 \\
\hline 2013 & 1413,3 & 633,4 & 325,7 & 22,6 & 2782,1 & 553,8 & 125,7 & 27,1 \\
\hline 2014 & 1160,6 & 541,4 & 270,1 & 21,3 & 2283,4 & 434,1 & 84,6 & 24,0 \\
\hline 2015 & 854,0 & 453,0 & 225,8 & 18,8 & 1971,9 & 377,4 & 67,9 & 19,7 \\
\hline 2016 & 1094,0 & 404,5 & 222,8 & 18,8 & 2029,9 & 418,8 & 73,1 & 34,1 \\
\hline 2017 & 744,4 & 384,3 & 223,6 & 17,4 & 1986,9 & 343,3 & 46,8 & 13,5 \\
\hline 2018 & 716,7 & 385,7 & 206,5 & 16,8 & 1974,9 & 342,2 & 54,1 & 21,2 \\
\hline 2019 & 695,8 & 383,9 & 205,1 & 17,9 & 2003,6 & 336,8 & 65,7 & 24,6 \\
\hline 2020 & 621,9 & 371,2 & 215,9 & 17,6 & 2065,7 & 276,6 & 55,3 & 22,3 \\
\hline
\end{tabular}

Джерело: [18]

Найбільше викидів забруднюючих речовин спостерігалося у 2011 р. - 6106,9 т/рік. Якщо прийняти загальну кількість тон викидів за $100 \%$, то за досліджуваний період серед усіх речовин найбільший вплив на якість повітря мали оксид вуглецю - 49,19\%; діоксид сірки - 22,42\%; та оксиди азоту - 9,75\%. Натомість у 2020 р. рівень забруднення повітря був відносно допустимим і становив 3646,5 тон шкідливих речовин проти 6106,9 тон у 2011 р., коли повітря було найбільш забрудненим шкідливими речовинами.

Отже, аналіз динаміки забруднюючих речовин в атмосферне повітря України за 2000-2020 рр. дозволяє стверджувати, що, незважаючи на позитивну динаміку до зменшення викидів шкідливих речовин у повітря, забруднення повітря має накопичувальний згубний вплив. Тому, й екологічний слід від діяльності автотранспорту та роботи обладнання усіх видів економічної діяльності буде погіршуватися.

Висновки і перспективи подальших розвідок. $\mathrm{Ha}$ сьогоднішній день гостро постає проблема екологічного сліду від діяльності людини, особливо в частині використання палива. Під час згорання палива виділяються шкідливі речовини, які шкодять навколишньому природному середовищу. Серед найбільш важких 
виокремлюються чадний та вуглекислий газ, оксиди азоту, вуглеводні, сажа, бензпірен, важкі метали. Всі ці елементи мають негативний вплив на здоров'я людей та погіршують якість повітря. Тому, вирішення екологічних проблем як в транспортному, так і в промисловому секторі України дасть можливість не тільки значно зменшити техногенне навантаження на довкілля, а й сприятиме збереженню унікальних природних та історико-культурних ландшафтів, знижуючи рівень екологічного сліду.

3 метою ідентифікації рівня викидів в цілому по Україні належним чином має формуватися звітність господарюючих суб'єктів, зокрема статистична. Своєю чергою на якість їі підготовки впливає рівень організації бухгалтерського обліку як комплексу заходів, дій та методів, спрямованих на побудову, впорядкування й удосконалення системи бухгалтерського обліку з метою здійснення його контрольної функції за раціональним використанням ресурсів та створення підґрунтя задля формування достовірної інформації, необхідної для потреб управління.

1.Качмар О.В. Теоретичні основи організації бухгалтерського обліку на підприємстві. Ефективна економіка. 2014. №9. URL: http://www.economy.nayka.com.ua/?op=1\&z=3367 (дата звернення: 28.08.2021). 2. БондаренкоН.М. Теоретичні основи організації обліку на підприємстві. Науковий вісник Херсонського державного університету. 2014. № 4. С. 10-14. 3. ВасільєваЛ.М., Чепець О.Г. Поняття та основні передумови раціональної організації обліку. Інвестиції: практика та досвід. 2013. №14. С.31-33. 4. Фабіянська В. Сутність організації бухгалтерського обліку. Українська наука: минуле, сучасне, майбутнє. 2014. № 19. С. 214-222. 5. Гуцайлюк Л., Шулякова А. Організація обліку на підприємствах різних форм власності: стан та перспективи розвитку. Науковий вісник МНУ імені В. Сухомлинського. 2018. № 2 (11). С. 146151. 6. Щодо паливно-мастильних матеріалів: лист Державного Комітету України з питань технічного регулювання та споживчої політики від 31.07.2009 р. № 78551-5/19. URL: https://zakon.rada.gov.ua/rada/show/v7855609-09?lang=uk\#Text (дата звернення: 30.08.2021). 7. Податковий кодекс України: від 02.12.2010 р. № 2755VI. URL: https://zakon.rada.gov.ua. (дата звернення: 30.08.2021). 8. Методичні рекомендації щодо облікової політики підприємства: наказ Міністерства фінансів України від 27.06.2013 р. № 635. URL: https://zakon.rada.gov.ua (дата звернення: 30.10.2021). 9. Кротю. Талони, смарт- та скретч-картки на пальне: що та як правильно застосовувати. Бюджетна бухгалтерія. 2015. № 41. URL: https://i.factor.ua/ukr/journals/bb/2015/november/issue-41/article-13063.html (дата звернення: 31.08.2021). 10. Норми витрат палива і мастильних матеріалів на автомобільному транспорті: затв. наказом Міністерства транспорту України від 10.02.1998 р. № 43. URL: https://zakon.rada.gov.ua/rada/show/v0043361-98\#Text (дата звернення: 31.08.2021). 11. Екологічний слід. Вікіпедія. 2019. URL: https://uk.wikipedia.org/wiki/\%D0\%95\%D0\%BA\%D0\%BE\%D0\%BB\%D0\%BE\%D0\%B3 \%D1\%96\%D1\%87\%D0\%BD\%D0\%B8\%D0\%B9_\%D1\%81\%D0\%BB\%D1\%96\%D0\%B4 (дата звернення: 28.08.2021). 12. Perkins $\bar{S}$. The best way to reduce your carbon footprint is one the government isn't telling you about. Science. 2017. URL: 
https://www.science.org/content/article/best-way-reduce-your-carbon-footprintone-government-isn-t-telling-you-about (дата звернення: 28.08.2021). 13. Ripple W. J., Wolf C., Newsome T. M., Galetti M., Alamgir M., Crist E., Mahmoud M. I., Laurance W. F. World Scientists' Warning to Humanity: A Second Notice. BioScience. 2017. No. 12. URL: https://doi.org/10.1093/biosci/bix125 (дата звернення: 28.08.2021). 14. Carrington D. Avoiding meat and dairy is 'single biggest way' to reduce your impact on Earth. The Guardian. 2018. URL: https://www.theguardian.com/environment/2018/may/31/avoiding-meat-and-dairyis-single-biggest-way-to-reduce-your-impact-on-earth дата звернення: 28.08.2021). 15. Викиди від транспорту і як з ними боротися. Федерація роботодавців автомобільної галузі. $2020 . \quad$ URL: https://fra.org.ua/uk/an/publikatsii/analitika/vikidi-vid-transportu-i-iak-z-nimiborotisia (дата звернення: 30.08.2021). 16. Павленко О.В. Актуальні питання забруднення атмосферного повітря. Державна екологічна інспекція України. 2021. URL: https://www.dei.gov.ua/posts/1563 (дата звернення: 30.08.2021). 17. Огляд стану забруднення навколишнього природного середовища на території України за I півріччя 2021 року (за даними спостережень Національної Гідрометслужби України). Центральна геофізична обсерваторія імені Бориса Срезневського. 2021. 19 с. 18. Економічна статистика. Навколишнє природне середовище. Державна служба статистики України. 2021. URL: http://www.ukrstat.gov.ua/operativ/menu/menu_u/ns.htm (дата звернення: 30.08.2021).

\section{REFERENCES:}

1. Kachmar O. V. Teoretychni osnovy orhanizatsii bukhhalterskoho obliku na pidpryiemstvi. Efektyvna ekonomika. № 9. URL: http://www.economy.nayka.com.ua/?op=1\&z=3367 (data zvernennia: 28.08.2021). 2. Bondarenko N. M. Teoretychni osnovy orhanizatsii obliku na pidpryiemstvi. Naukovyi visnyk Khersonskoho derzhavnoho universytetu. 2014. № 4. S. 10-14. 3. Vasilieva L. M., Chepets 0 . H. Poniattia ta osnovni peredumovy ratsionalnoi orhanizatsii obliku. Investytsii: praktyka ta dosvid. 2013. № 14. S. 31-33. 4. Fabiianska V. Sutnist orhanizatsii bukhhalterskoho obliku. Ukrainska nauka: mynule, suchasne, maibutnie. 2014. № 19. S. 214-222. 5. Hutsailiuk L., Shuliakova A. Orhanizatsiia obliku na pidpryiemstvakh riznykh form vlasnosti: stan ta perspektyvy rozvytku. Naukovyi visnyk MNU imeni V. Sukhomlynskoho. 2018. № 2 (11). S. 146151. 6. Shchodo palyvno-mastylnykh materialiv: lyst Derzhavnoho Komitetu Ukrainy z pytan tekhnichnoho rehuliuvannia ta spozhyvchoi polityky vid $31.07 .2009 \mathrm{r}$. № 7855-1-5/19. URL: https://zakon.rada.gov.ua/rada/show/v785560909?lang=uk\#Text 7. Podatkovyi kodeks Ukrainy vid 02.12.2010 r. № 2755-VI. URL: https://zakon.rada.gov.ua. (data zvernennia: 30.08.2021). 8. Metodychni rekomendatsii shchodo oblikovoi polityky pidpryiemstva: zatv. nakazom Ministerstva finansiv Ukrainy vid 27.06.2013 r. № 635. URL: https://zakon.rada.gov.ua (data zvernennia: 30.08.2021). 9. Krot Yu. Talony, smart- ta skretch-kartky na palne: shcho ta yak pravylno zastosovuvaty. Biudzhetna bukhhalteriia. 2015. № 41. URL: https://i.factor.ua/ukr/journals/bb/2015/november/issue-41/article-13063.html (data zvernennia: 31.08.2021). 10. Normy vytrat palyva i mastylnykh materialiv na avtomobilnomu transporti: zatv. nakazom Ministerstva transportu Ukrainy vid 10.02.1998 r. № 43. URL: https://zakon.rada.gov.ua/rada/show/v0043361-98\#Text (data zvernennia: 31.08.2021). 11. Ekolohichnyi slid. Vikipediia. 2019. URL: 
https://uk.wikipedia.org/wiki/\%D0\%95\%D0\%BA\%D0\%BE\%D0\%BB\%D0\%BE\%D0\%B3 \%D1\%96\%D1\%87\%D0\%BD\%D0\%B8\%D0\%B9_\%D1\%81\%D0\%BB\%D1\%96\%D0\%B4 (data zvernennia: 28.08.2021). 12. Perkins S. The best way to reduce your carbon footprint is one the government isn't telling you about. Science. 2017. URL: https://www.science.org/content/article/best-way-reduce-your-carbon-footprintone-government-isn-t-telling-you-about (data zvernennia: 28.08.2021). 13. Ripple W. J., Wolf C., Newsome T. M., Galetti M., Alamgir M., Crist E., Mahmoud M. I., Laurance W. F. World Scientists Warning to Humanity: A Second Notice. BioScience. 2017. No. 12. URL: https://doi.org/10.1093/biosci/bix125 (data zvernennia: 28.08.2021). 14. Carrington D. Avoiding meat and dairy is single biggest way to reduce your impact on Earth. The Guardian. $2018 . \quad$ URL: https://www.theguardian.com/environment/2018/may/31/avoiding-meat-and-dairyis-single-biggest-way-to-reduce-your-impact-on-earth data zvernennia: 28.08.2021). 15. Vykydy vid transportu i yak z nymy borotysia. Federatsiia robotodavtsiv avtomobilnoi haluzi. 2020. URL: https://fra.org.ua/uk/an/publikatsii/analitika/vikidivid-transportu-i-iak-z-nimi-borotisia (data zvernennia: 30.08.2021). 16. Pavlenko 0. V. Aktualni pytannia zabrudnennia atmosfernoho povitria. Derzhavna ekolohichna inspektsiia Ukrainy. 2021. URL: https://www.dei.gov.ua/posts/1563 (data zvernennia: 30.08.2021). 17. Ohliad stanu zabrudnennia navkolyshnoho pryrodnoho seredovyshcha na terytorii Ukrainy za I pivrichchia 2021 roku (za danymy sposterezhen Natsionalnoi Hidrometsluzhby Ukrainy). Tsentralna heofizychna observatoriia imeni Borysa Sreznevskoho. 2021. 19 s. 18. Ekonomichna statystyka. Navkolyshnie pryrodne seredovyshche. Derzhavna sluzhba statystyky Ukrainy. 2021. URL: http://www.ukrstat.gov.ua/operativ/menu/menu_u/ns.htm (data zvernennia: 30.08.2021).

Pavelko 0. V. [1; ORCID ID: 0000-0002-2483-2245], Dr. of Economics, Professor, Velihurska A. M. [1; ORCID ID: 0000-0002-4261-9739], applicant for the second (master's) level of higher education, Livenda K. 0. [1; ORCID ID: 0000-0001-9442-7619], applicant for the second (master's) level of higher education

${ }^{1}$ National University of Water and Environmental Engineering, Rivne

\section{FUEL ACCOUNTING ORGANIZATION AS A COMPONENT OF INFORMATION SUPPORT OF ENVIRONMENTAL TRACE MANAGEMENT}

The article examines the identification of the organization of accounting, author's interpretation is offered. The organization of accounting is supposed to be a set of measures, actions and methods aimed at building, streamlining and improving the accounting system in order to exercise its control function over the rational use of resources and create a basis for the formation of reliable information, which is necessary for management. 
The stages of organizing the fuel accounting process as one of the main exhaustive and expensive resources for the operation of cars, which during combustion in the engine causes emissions of substances dangerous to human health and the environment, are defined.

It is established that the generalization of information on the amount of fuel used is a necessary condition for assessing the level of pollutant emissions into the atmosphere, taking effective measures to reduce the level of anthropogenic impact on the environment, which in turn is reflected in the "environmental footprint". Forms of statistical reports, which contain information about fuel and volumes of its use are given. Relevant indicators of statistical reports are characterized. The content of the main pollutants in the air of Ukrainian cities according to the observations of hydrometeorological organizations is analyzed. The dynamics of pollutant emissions into the air of Ukraine for 2000-2010 is given. Thus, the analysis of the dynamics of pollutants in the air of Ukraine for 2000-2020 allows us to state that despite the positive dynamics to reduce emissions of harmful substances into the air, air pollution has a cumulative detrimental effect. Therefore, the environmental footprint of the activities of vehicles and equipment of all types of economic activity will deteriorate.

Solving environmental problems in both the transport and industrial sectors of Ukraine will not only significantly reduce the manmade load on the environment, but also contribute to the preservation of unique natural and historical and cultural landscapes, while helping to reduce the level of ecological footprint.

Keywords: organization of accounting; fuel; information support; management; ecological footprint.

Павелко О. В. [1; ORCID ID: 0000-0002-2483-2245], д.э.н., профессор,

Велигурская А. М. [1; ORCID ID: 0000-0002-4261-9739], соискатель второго (магистерского) уровня высшего образования, Ливенда Е. А. [1; ORCID ID: 0000-0001-9442-7619], соискатель второго (магистерского) уровня высшего образования

1 Национальный университет водного хозяйства и природопользования, г. Ровно

ОРГАНИЗАЦИЯ УЧЕТА ТОПЛИВА КАК СОСТАВЛЯЮЩАЯ
ИНФОРМАЦИОННОГО ОБЕСПЕЧЕНИЯ УПРАВЛЕНИЯ
ЭКОЛОГИЧЕСКИМ СЛЕДОМ

В статье исследована идентификация организации бухгалтерского учета, предложено ее авторское толкование. Определены этапы организации учетного процесса топлива как 
одного из главных исчерпывающих и дорогостоящих ресурсов для работы автомобилей, что при сгорании в двигателе приводит к выбросам опасных для здоровья людей и окружающей среды веществ. Установлено, что обобщение информации об объемах использованного топлива является необходимым условием оценки уровня выбросов загрязняющих веществ в атмосферу, принятие действенных мер по снижению уровня антропогенного воздействия на окружающую среду, что в свою очередь отражается в показателе «экологический след». Приведены формы статистической отчетности, содержащие сведения о топливе и объемах его использования. Наведены соответствующие показатели статистической отчетности. Проанализировано содержание основных загрязняющих веществ в атмосферном воздухе Украины по данным наблюдений гидрометеорологических организаций. Исследована динамика выбросов загрязняющих веществ в атмосферный воздух Украины за 2000-2010 гг.

Ключевые слова: организация учета; топливо; информационное обеспечение; управление; экологический след. 